institutions in Europe, Canada, and the United States. Members of the International African Seminar on the Social Implications of Multilingualism in Eastern Africa-sponsored by the International African Institute in cooperation with the Survey (see Africa, xxxix. 2 (1969), p. 177)-also participated in many of the sessions. Subjects discussed ranged from the preparation of teaching materials and examinations, the teaching of languages in the region, to literacy problems, language in adult education, and linguistic description. Arrangements are now being made for the eventual publication of a selection of the papers presented.

The formation of the Language Study Group of Ethiopia, the Kenya Language Association, the Language Association of Tanzania, the Uganda Language Society, and the Zambia Language Group should be of considerable assistance to the Survey in continuing at least some of its activities, and a Regional Language Association Steering Committee, consisting of a representative from each of these five national organizations, has been formed to draft a constitution and to present its programme to the next meeting of the Survey Council.

\title{
The Collection of African Oral Traditions
}

A MEETING to discuss the co-ordination and planning of the collection of African oral traditions was held in Ouagadougou, Haute-Volta, from 29 July to 2 August 1968, under the joint organization of the Government of Haute-Volta and the Cultural Division of UNESCO. UNESCO was represented by Maurice Glélé, Organizer of programmes for the study of African cultures, and Enrico Fulchignoni, head of the section for creative arts. Joseph Ki-Zerbo of Haute-Volta was elected president, J. F. Ade Ajayi of Nigeria and Jean Rouch vice-presidents, and Dijbril Tamsir Niane of Guinea official reporter of the meeting. The aim was to provide an outline of work for those in charge of centres, institutes, and research programmes. Most of the countries officially represented came from the West African region and discussion was concentrated on problems of historical research in West Africa.

The first plenary sessions were occupied by a discussion of Joseph Ki-Zerbo's paper on 'Oral traditions as a source of African history', followed by progress reports on the collection of oral traditions presented by those responsible for national research programmes. One working session was concerned with the association between the cinema and oral tradition. Papers by F. N. Agblemagnon, J. F. A. Ajayi, E. J. Alagoa, R. G. Armstrong, O. Ba, T. Boly, K. Dittmer, J. A. Djivo, J. D. Hargreaves, J. Hébert, J. J. Holden, A. Iliasu, M. Izard, M. Johnson, D. H. Jones, D. T. Niane, R. Pageard, M. Posnansky, W. Rodney, A. Salifou, B. B. Some, S. Tall, and J. Zwernemann were presented or distributed in absentia at the meeting. The final report, distributed at the end of the meeting, listed a number of agreed projects. Those for the southern borders of the Sahara and the savanna zone included: the Peul, the Mossi-Dagomba group, the Hausa, the Kanuri, the 'River Niger-Songhai ' project, the 'Gourmantché ' project, the 'Kurumba-Tellem ' project, and the ' O.E.R.S. project', presented by the Organization of Senegal River States. Those for the coastal and forest zones were: the Mande-Gonja, the Borgu, the Ewe-Adja-Yoruba-Fon, and the Western Akan-Agni-Baule. Collecting operations will be co-ordinated from Niamey, with a subsidiary centre, perhaps Accra, for the forest zone.

It was proposed that the Centre voltaique de la recherche scientifique in Ouagadougou should set up various historical card indexes and publish a bilingual information bulletin on historical research in West Africa. A further proposal was for special efforts to be made in collecting the oral traditions of groups with specific social and economic functionsblacksmiths, potters, musicians, etc. Two further meetings in this series have been agreed in principle: one on the problems of applied linguistics in historical work; and the other on the standardization of personal and place-names in West African history. 